\title{
Collapsing the Boundaries Between De Jure and De Facto Slavery: The Foundations of Slavery Beyond the Transatlantic Frame
}

\author{
Katarina Schwarz ${ }^{1}$ (D) Andrea Nicholson ${ }^{2}$
}

Published online: 3 September 2020

(C) The Author(s) 2020

\begin{abstract}
The identification of contemporary forms of slavery is often problematically demarcated by reference to transatlantic enslavement as the definitive archetype. Such an approach overlooks other historic slaveries and neglects the totality of the maangamizi - the African holocaust. This article addresses the problematics of positioning the transatlantic system as the paradigm and unpacks the constituent elements of de jure slavery to construct an understanding of slavery as a condition as well as a status. By identifying the core features of de jure chattel slavery through time, this paper displaces the assumption that legal status is determinative, giving meaning to the concept of slavery in the contemporary world.
\end{abstract}

Keywords Slavery $\cdot$ Modern slavery $\cdot$ Human rights $\cdot$ Maangamizi $\cdot$ Definition

\section{Introduction}

Slavery has existed throughout human history, yet the parameters of the institution continue be contested. Such disputes are particularly acute in the consideration of 'modern slavery' - that is, enslavement and related exploitation in the contemporary world. 'Modern slavery' scholars and activists assert the continued relevance of slavery, in some cases extending slavery as an umbrella term capturing a range of otherwise separately defined practices, ${ }^{1}$ and in others presenting it as a discrete and holistic concept (see Bales

\footnotetext{
${ }^{1}$ This approach most commonly includes servitude, forced labour, human trafficking, and forced marriage as forms of 'modern slavery', for instance International Labour Organisation and Walk Free Foundation (2017) and the Modern Slavery Act (2015).
}

Katarina Schwarz

Katarina.Schwarz@nottingham.ac.uk

1 The Rights Lab and School of Law, University of Nottingham, Nottingham, UK

2 The Rights Lab and School of Politics and International Relations, University of Nottingham, Nottingham, UK 
2005, p 9). 'Critical modern slavery' scholars, on the other hand, challenge the language of 'modern slavery', in some instances arguing for wholesale abandonment of the concept of slavery in the contemporary world (O'Connell Davidson 2015), and in others advocating greater limitations on its application (Chuang 2015). But, far from a binary debate, a diversity of perspectives on the content and parameters of the institution have developed over time (and with increased frequency in recent years), defining the contours and parameters of slavery in a plethora of different ways. ${ }^{2}$

Very often in contemporary deliberations over the nature and contours of slavery, the image of nineteenth century transatlantic enslavement ${ }^{3}$ serves as a backdrop to the conceptualisation of the institution - an uncontested and archetypical instance of enslavement based on racialised legal ownership of persons. However, the perspectives and insights of activists and scholars advocating for reparatory justice for the system of transatlantic enslavement problematise these assumptions. While some scholars look beyond the example of transatlantic enslavement in conceptualising the institution more broadly (Brion Davis 2006; Finley 1998; Patterson 2018), its position as a paradigm is rarely questioned. This article therefore interrogates the transatlantic paradigm, considering both its content and its positioning in debates over the definition of slavery. This demands a move beyond the transatlantic system to reconsider the foundations of slavery.

This article then takes a subject of consensus rather than contention as its point of entry: the paradigm of de jure chattel slavery (legal ownership of persons enshrined in law). Drawing on a diversity of historic slaveries, we explore the centrality of the property frame and unpack the core features of de jure chattel slavery. Having explored these features, we ask a crucial question for the debate over 'modern slavery': is there something fundamentally distinct about de jure slavery that precludes recognition of slavery absent the legal status of such? Interrogating the boundaries between de jure and de facto slavery, we reveal presumed demarcation to be illusory, arbitrary, or immaterial in light of the core features of de jure slavery. We therefore argue that distinctions that arise do not lead to a rejection of the existence of de facto or contemporary slavery, but do have the consequence of narrowing the parameters of 'modern slavery', in contrast to wider interpretations.

\section{Beyond the Transatlantic Paradigm}

The system of transatlantic chattel enslavement is the dominant image of slavery in contemporary discourse. Contemporary antislavery actors often point to the memory of transatlantic enslavement as the paradigm against which exploitation today can be

\footnotetext{
${ }^{2}$ Another dominant school of thought in this regard delineates various different forms of exploitation, some of which might constitute or rise to the level of slavery, while others do not. This approach is often based on legal argumentation, see for instance Allain (2012), Chuang (2014, 2015).

${ }^{3}$ We acknowledge that the language of 'transatlantic slavery' and 'transatlantic slave trade' is common and dominant in academic and public discourse. However, in light of the problematisation of this language by reparations activists (see e.g. INOSAAR 2017), we prefer the language of 'transatlantic enslavement' and the 'transatlantic system' in this paper. 'Enslavement' in this context may refer to the experience of slavery, and not only the process of entering into it. Likewise, the language of 'enslaved persons' and 'persons held in slavery' are preferred over 'slaves'. This language is preferred throughout the piece, except where required by the context, the specific subject of analysis, or as a direct quotation.
} 
understood and condemned. Antislavery activists draw direct conceptual, rhetorical, and visual parallels between the experiences of enslaved people within the transatlantic system, and those of people experiencing human trafficking and 'modern slavery' today (see O'Connell Davidson 2017, p 1; Kurasawa 2014). The memory of transatlantic enslavement is evoked both to explain the experience of 'modern slavery' and to agitate for antislavery action (Quirk 2008; Trodd 2013). In many ways, this has proven to be an effective frame and tactic for the contemporary antislavery movement, at least in part by drawing upon the universal consensus decrying the transatlantic system that developed from nineteenth century abolitionism (see D'Anjou and Van Male 1998; Snow and Benford 1992). The shift in public attitudes on the moral status of transatlantic slavery was largely completed in the twentieth century, to the extent that the prohibition against slavery is now recognised as one of the few jus cogens norms of international law carrying obligations erga omnes. ${ }^{4}$ That is to say, that slavery achieved universal legal opposition. Modern antislavery advocates therefore draw on the widespread moral opprobrium attaching to transatlantic enslavement in order to advance their contemporary cause.

Critics of the 'modern slavery' movement problematise the use of the memory of transatlantic enslavement in this contemporary context, suggesting variously: that the lack of parity between transatlantic enslavement and contemporary forms of human exploitation mean that the latter fail to qualify as 'slavery' (O'Connell Davidson 2017); that the use of slavery in contemporary activism 'whitewashes' or minimises the history of transatlantic enslavement (Bravo 2011); and that 'modern slavery' is a distraction tactic to avoid addressing the continuing legacies of transatlantic enslavement on the lives of people of African descent (Beutin 2017). These critiques contribute to a broader set of criticisms of 'modern slavery' scholarship and action, questioning both the language of slavery in the contemporary context, and its existence. In this debate, the characterisation of exploitation within the system of transatlantic chattel enslavement as slavery is situated as one of the few points of agreement (see for instance O'Connell Davidson 2015). In other words, the transatlantic archetype remains at the heart of the analysis.

From modern slavery advocacy to critique, the images and experiences of transatlantic enslavement are used to explain the conceptual boundaries of slavery as an institution. At a minimum, the transatlantic system is widely accepted as slavery, properly called. Yet, the institution of slavery far predates European incursions into the West Coast of Africa and 'discovery' of the Americas. Both slavery and its internationalisation trace back through thousands of years of human history, to the extent that Eltis and Engerman (2011, p 3) argue that it is not enslavement, but the paradigm of free labour that constitutes the historical exception, with institutionalised coercive relationships representing the norm until the twentieth century. Miller (2008, p 70) likewise labels slavery a 'recurrent historical dialectic', while Patterson (1982, p i) highlights that there is 'nothing notably peculiar about the institution of slavery', having existed throughout human history and in every region of the world.

\footnotetext{
${ }^{4}$ The status of the prohibition of slavery as such a norm was recognised by the International Court of Justice in the Case concerning the Barcelona Traction, Light and Power Company Ltd (Belgium v Spain) [1970], para 34. As a result of this status, the prohibition against slavery is considered binding on all States, permitting of no derogation, and any breaches considered an affront to the international community as a whole - see Allain (2019).
} 
Enslavement infuses human history, from Ancient Greece, Rome, and the Near East, to the Sassanian, Abyssinian, and Akkadian Empires, from the first 'global economies' in the Indian Ocean and Asian worlds, to early Islamic law, Hindu Rajyas, medieval Korea, and early Christianity. ${ }^{5}$ Systems of enslavement took root in Mesopotamia as early as the third millennia BCE (Goody 1980). In the ancient Near East, from a very early period, persons were, and could be, bought and sold within a framework fitting the 'traditional definition of slavery', involving the imposition of social death and dishonour (Snell 2011, pp. 4-5). In ancient Rome, mass enslavement and the growth of the 'slave society' took root in the third century BCE, and escalated rapidly in the second to reach between twenty and $30 \%$ of the population by the late first century BCE (Joshel 2010, p 55-56). ${ }^{6}$ In ancient Greece, the 'slave trade was everywhere', both physically and ideologically, and enslavement, 'slave trading', and the commodification of human beings were normalised practices (Braund 2011, pp. 112-113). Yet, despite the apparent universality of enslavement through time, different forms of exploitation have manifested in different contexts at different times (see Patterson 1982; Quirk 2011). As Dockès (1982, p 49) suggests: 'The nature of slavery changes from one period of history to another, and, within a given period, it varies from one region to the next. Even in one particular spot at one moment in time, quite different kinds of slaves are found.'

While transatlantic enslavement might serve as a sensible starting point for determining the contours and boundaries of the institution of slavery in some contexts, it is clearly not the sole touchstone. Moreover, conceptualisations that rely only on the experience of transatlantic chattel enslavement to describe and define slavery risk minimising the abuses committed against African people and people of African descent within the transatlantic system. These references typically treat the transatlantic system of chattel enslavement and associated violations (as a whole) as the image of enslavement, rather than drawing a distinction between enslavement and other related abuses within this system. Thus the 'transatlantic paradigm' of slavery is often constructed as encompassing the system as a whole, rather than focusing specifically on slavery within it.

Contemporary scholars and activists dedicated to advancing the case for reparatory justice for the history and legacies of transatlantic enslavement illuminate the difficulties of taking transatlantic chattel enslavement as the paradigm of slavery. Although recognising that enslavement was an undeniable aspect of the system of abuse, reparationists argue that neither 'slavery' nor 'slave trading' are appropriate or complete descriptions of the transatlantic system. It is against this backdrop that reparations activists advance the language of the maangamizi - the African holocaust of chattel, colonial, and neo-colonial enslavement (Karenga 2001; Stanford-Xosei 2015; Laccino 2016). ${ }^{7}$ The maangamizi recognises the placement of enslavement within a broader framework of violence committed against African and indigenous peoples, acknowledging that enslavement in this context did not occur in a vacuum (see further Gifford

\footnotetext{
${ }^{5}$ See generally Heuman and Burnard (2011) and Patterson (2018). On slavery in ancient Greece, Rome, and the Near East see McKeown (2010) and Fisher (1993). On slavery in Asia, see Reid (1983) and Watson (1980). On Islamic law of slavery see Freamon (2012). On slavery in early Christianity, see Glancy (2002).

${ }^{6}$ This equated to a figure of 1 to 1.5 million enslaved persons in a population of 5 to 6 million.

${ }^{7}$ In some instances, the term maafa is used in place of maangamizi (for instance, Wittmann 2012). These terms share the same Kiswahili roots, however, maangamizi entails an element of intentionality not reflected in maafa.
} 
2007, p 93). As Karenga (2001, p 2) explains: 'By holocaust we mean a morally monstrous act of genocide that is not only against the people themselves, but also a crime against humanity. The Holocaust of enslavement expresses itself in three basic ways: the morally monstrous destruction of human life, human culture and human possibility.'

The term maangamizi places the specific injustices of transatlantic enslavement within their broader context, recognising not only that individuals were victims of enslavement, but also that this treatment was intentionally perpetrated, widespread, specifically targeted towards Africans and their descendants, and interwoven with a range of related abuses (INOSAAR 2017; Karenga 2001; Schwarz 2019). On this account, the failure to recognise the system of transatlantic enslavement as something more than just 'slavery' or a 'slave trade' (as is the case when it is taken as the paradigm of slavery) contributes to the sanitisation and forgetting of the history of atrocities committed against African peoples and societies (Karenga 2001). In short, it distils the experience of a holocaust down to slavery alone.

Recognising that the experiences of those enslaved within the system of transatlantic enslavement encompassed grave discrimination, violence, kidnapping, rape, mass murder, genocide, and other atrocities, as well as slavery, shifts the role of the transatlantic paradigm in formulating a conceptual understanding of slavery as a remarkably stubborn institution across time. While these abuses were interrelated in the context of the maangamizi as a whole, they did not necessarily manifest in every individual experience of enslavement within the transatlantic system. Some of the abuses may have been absent in particular cases, without obviating the existence of slavery. Nor did every violation committed within the maangamizi include enslavement. To treat the maangamizi as a whole as constitutive and descriptive of slavery, is to overlook this wider pattern of systematic abuses. Thus, while recognition of the maangamizi permits consideration of the specific manifestations and dynamics of enslavement within the transatlantic system, it precludes treating the transatlantic system as simply 'slavery' or 'slave trading'. This requires a shift in the understanding of transatlantic enslavement used as a reference point for conceptualising slavery, to a focus on enslavement within the transatlantic system, rather than the system as a whole. It also invites a shift away from the transatlantic paradigm as the sole or primary reference point for defining slavery, as it is no longer positioned as definitive of slavery, but rather a holocaust in which slavery formed a key component.

Combined, the recognition of historic forms of slavery in diverse contexts and the transatlantic system as maangamizi establish the need to move away from the transatlantic paradigm as the basis for understanding slavery as a concept and an institution, and thus for identifying slavery in the contemporary context. Defining the nature and borders of slavery necessitates looking beyond the specific manifestations of violence in a single context — whether transatlantic enslavement or other historical examples - to discover those elements that are inseparable from the experience of enslavement across cases and through time. Slavery is a conceptual category of experience not defined by each and every aspect of slavery represented across cases, but by the core constituent elements common to all. 


\section{Conceptualising De Jure Slavery}

Moving beyond the transatlantic paradigm as a starting point for understanding slavery, another archetype remains at the core of many conceptualisations of slavery through time: slavery as a legal status created when people are held as property in law (de jure chattel slavery). While commentators often dispute the margins of slavery, there is very little argument over the status of de jure chattel slavery as slavery properly called. Rather than being tied to a particular instance of slavery, the paradigm of de jure chattel slavery is carried through many different historical instances of slavery, giving it wider relevance. In order to identify the nature of slavery, the features and experiences of persons held in de jure chattel slavery are therefore a useful starting point for considering the institution as a whole. Unpacking the constituent elements of the experience of de jure chattel slavery exposes core elements of a broadly accepted and uncontested form of slavery (including from the perspectives of commentators with otherwise widely diverging views). These core elements can then be reconceptualised through consideration of the points of mimicry and departure from instances of exploitation that might amount to de facto slavery. This then invites a reconsideration of the presumed boundaries between de jure and de facto slavery, and provides a new foundation for consideration of marginal cases in which the application of the moniker of slavery is contested.

The framework of property law-property rights in, and ownership of, personsdelimits the parameters of traditional chattel slavery. In the words of the European Court of Human Rights (Siliadin v France 2005, para 122), the 'classic' meaning of slavery entails a 'genuine right of legal ownership' over a person, reducing them to the status of an 'object'. Smith (1954) likewise contends that slavery is characterised by the 'legal assimilation of interpersonal rights to the norm of property rights over things'. Hunt (2017) notes that 'historians define slavery in terms of property' rather than by the nature of the treatment of persons enslaved, and Nieboer (1971) suggested that slavery 'is the fact that one man is the property or possession of another'. This was definitively true of transatlantic enslavement, in which the characterisation of Africans and people of African descent as chattel (things) in law, and the tapestry of associated legal protections that gave effect to this property right in persons, were the foundation for the system of institutionalised enslavement. ${ }^{8}$ Likewise, in recognised slave societies throughout history, slavery has often existed primarily as a legal status wherein property rights could be exercised over a person and upheld through legal or equivalent customary institutions. ${ }^{9}$

This reflects a global orthodoxy in which property frameworks - those legal institutions that regulated slavery for centuries - are the lens through which the practical and theoretical boundaries of the phenomenon of (chattel) slavery are to be viewed (Allain and Hickey 2012). Freamon (2012, p 41) highlights that the basic definition of slavery in Islamic law was 'firmly rooted in property concepts while haltingly recognizing the humanity of the slave'. Bradley (2011, p 242) describes enslaved persons in

\footnotetext{
${ }^{8}$ For instance, the preamble to the Barbados Slave Code of 1661 articulated the law's purpose as protecting enslaved persons 'as we do men's other goods and chattels'.

${ }^{9}$ On the centrality of the property frame, see also Elkins (1959, p 55), Tannenbaum (1992, p 82), Stampp (1956).
} 
the Roman Republic (late sixth century to late first century BC) as 'items of property over which their owners had complete powers of disposal'. States around the world have demonstrated consensus on the centrality of property law in defining slavery in the negotiation and adoption of the 1926 Slavery Convention (Hickey 2012, p 221), which defines slavery by reference to the 'powers attaching to the right of ownership' (League of Nations 1926a, art 1). Defining slavery by reference to either legal ownership itself, or the exercise of powers attaching to the right of ownership, places the property paradigm at the centre of the conceptualisation of slavery.

The elements of the property frame must be unpacked in order to understand the manifestation of property over persons - that is, to understand de jure chattel slavery. Hickey (2012) identifies the traditional powers associated with ownership as possession, use, management, income, capital (transfer, total use, destruction), security (protection from unjust expropriation), transmissibility, absence of term (potentially limitless duration), and liability to execution. Although articulated in terms of broad and overarching powers, this framework does not require the powers of ownership be absolutely unlimited in order to be recognised as such. Some restrictions are permitted, although with the general presumption that the property interest of ownership is of a residuary character. That is, that the owner retains all property rights not vested in another or restricted by the State through legal mechanisms, and that property rights vest in the owner once all lesser rights and claims have been satisfied. This formulation of the content of property rights is founded in understandings of property law throughout history (Hickey 2012; Penner 2012). These powers encapsulate the manifestation of legal ownership in practice, and thus the boundaries of chattel slavery. Yet, while these powers individually evidence the incidents of the property relationship, alone they are insufficient to capture the essence of ownership.

Despite property being manifested in a series of powers exercised by the owner over the thing (or person) owned, there is something more in the relationship of ownership than these taken alone or in combination. ${ }^{10}$ The history of property law frameworks speaks to an intangible, additional element of the property relationship sitting behind the exercise of the powers identified, framing ownership as a relationship more extensive than mere usufructuary rights (rights to use or enjoy). Roman law framed ownership as dominus, presenting the owner as master of the thing owned, distinct from a mere user of that thing (see Nicholas 1976). Blackstone in the late eighteenth century framed ownership as a despotic relation of control between person and thing (Blackstone 1765), and civil law likewise conceived of ownership as dominium (Penner 1997, 2012). Civil law saw full ownership as manifested by usus (the right to use), fructus (the right to profit), and abusus (the right to alienate by consuming, destroying, or transferring) (Pierre 1997, p 253). Ownership in Islamic law connotes "exclusive possession... and can also signify "command", or "authority", "dominium" and "power" (Freamon 2012, p 46). In early modern China, statutory language on property rights did not delineate 'control' from 'ownership', treating these as indistinguishable and inseparable (Crossley 2011, p 187).

\footnotetext{
${ }^{10}$ This reflects the observation of the Belgian delegate in relation to the 1926 Slavery Convention, noting that the 'fact that any or all of the powers attaching to the right of ownership are exercised over a person does not necessarily mean that person is a slave'-Allain (2008).
} 
The frameworks of property identified above require more than simply use, management, profit, transfer, or disposal to constitute ownership - they require a threshold level of control over that which is owned. Thus, in light of the formulation of ownership in the property frame, chattel slavery turns not only on the exercise of any or all of the specific powers associated with ownership, but on the necessary underlying relationship of control tantamount to possession in which these are exercised (Hickey 2012; Research Group on the Legal Parameters of Slavery 2012). This control exerted by the enslaver requires and produces an equivalent alienation of control from the person enslaved. Yet, just as property rights in things need not be entirely unlimited to constitute ownership, the exercise of powers of property over persons need not be absolute in order to reach the necessary threshold of control.

The framework of ownership, with its residuary character, creates an institution that encapsulates the totality of the person, including their future. The reduction of a person to the status of a thing speaks indirectly to this element, and the final civil law element of full ownership - abusus - manifests concepts of both permanence and totality. In reducing a person to a thing, and enabling the disposal, gift, or exchange of the person themselves, and not only their labour, slavery encompasses the person enslaved as a whole and in absolute terms, and not merely the claim over some part of their life or action for a limited period. The centrality of these rights is echoed in South Africa's affirmation that 'from the proprietary interest of the other person in the person to whom that status attaches is implied a right of disposal, gift or exchange' (League of Nations 1926b). These powers require a level of control over a person (tantamount to possession) so as to enable the transfer of their life without the requirement of any consideration for their own wills or desires. Those enslaved are therefore treated as 'disposable', with the ability of the slaveholder to dispose of those enslaved correlating with rights to destroy property (abusus) and affording the slaveholder power over the life and death of the enslaved individual. This reflects the distinction between the exercise of usufructuary rights only, and ownership.

The implications of property's residuary character speak to the notion of the permanence of the institution of slavery. As the South African representative further noted, the nature of the exercise of proprietorship implies 'permanent status or condition of a person whose natural freedom is taken away' (League of Nations 1926b). Hunt (2017) argues that it is this element of (potential) permanence that distinguishes slavery from other forms of exploitation. Crossley (2011) notes that in early modern China, contracts claiming to place people in servitude (applying to people not legally permitted to be enslaved) were subsequently recognised as slavery, and the persons legally categorised as slaves, where the term of the contract was indefinite or extended for a sufficiently long period of time as to echo this. Jackson (2006) notes that the ancient world often differentiated between temporary 'debt slaves' and permanent 'foreign slaves' - with some Hebraic biblical sources rejecting the use of the term eved (slave) for the former, while the latter were true 'chattel slaves'. ${ }^{11}$ The elements of permanence and totality do not require the condition of enslavement be permanent in

\footnotetext{
${ }^{11}$ Clear delineation here is complicated by the labelling of those in temporary debt bondage as 'debt slaves', implying that beyond the paradigm of de jure chattel slavery (which is associated with permanence and totality) the role of term limits on the finding of slavery in other situations of slavery requires further interrogation.
} 
fact, but that during the period of enslavement the right to property in the person enslaved exists in perpetuity. ${ }^{12}$

A survey of historic enslavement evidences repeated motifs of abuse, objectification, and alienation, and a range of experiences that shape these motifs. These include the following: transitionary rituals and shaming tactics used by slaveholders to emphasise status, alienate, and control; the 'animalisation' of those enslaved; physical practices that undermine genderhood and sexuality; and denial of bodily ownership, including to what it produces (such as progeny and the fruits of labour-fructus). The practice of renaming and use of disparaging and demeaning language were employed in many slave societies to denote slave status and undermine individuals' social and self-held beliefs as to what was 'normal' (a means of nullifying their personalities and reframing their identities from free men to slaves). ${ }^{13}$ Enslaved persons also suffered a complete disregard for age and capacity as regards their wellbeing, a denial of privacy, and a profound lack of futurity (Nicholson 2018; Nicholson et al. 2018). ${ }^{14}$ All of these elements assured the deprivation of dignity, respect, and honour. The enslaved person's agency and autonomy were displaced, and their personhood, wellbeing, and futurity denied. This often entailed violent domination. As Bradley (2011, p 246) observes: 'The slave in this world is the ultimately degraded member of society, an object held in violating subjection...compelled by the ever-present threat of force to obey the instructions of the slave-owner.'

While abuse is central to enslavement, it is the possibility of violence and abuse that is significant. The violence those enslaved experienced, the level or type of abuse, or the living conditions in which they lived are not (in themselves) definitive of de jure slavery. Rather, the ability of the slaveholder to exercise that abuse, whether actual or threatened, is essential. For example, where the 'good slaveholder' may have provided comparably better conditions for those they held in slavery, they nevertheless exercised powers of ownership over these persons, and the decision as to whether or not to exercise force or brutality still rested with them. It is not the actual exercise of force that denotes enslavement, but the ability on the part of the slaveholder to exercise that force on a whim and with relative impunity. Even where de jure slaves were abandoned and held 'control over their social body' (Diaz 2006, p 31), that control was permitted, not unfettered. The returning slaveholder would have held the right to exercise the powers of ownership over them at any time; their social and legal status denying them power to contest their enslaved status. ${ }^{15}$ The social and legal marginalisation of these enslaved persons - the status that enabled their dehumanisation in law-could continue, irrespective of whether their enslaver was exercising the powers of ownership in any given moment.

\footnotetext{
$\overline{12}$ It should be recognised, however, that a right existing in perpetuity may nonetheless be alienated, making manumission, emancipation, or legally recognised exit from slavery possible.

${ }^{13}$ See e.g. Patterson (1982, p 55), Mendelsohn (1949), Austen (1977, p 132), Pulleyblank (1958, p 217).

${ }^{14}$ For further testimony identifying these factors, see the narrative collections at Documenting the American South (n.d.), Weld (2011), Yetman (2000), Blight (2009), Nicholson (2018).

${ }^{15}$ See for example, Julia O'Connell Davidson's example of the copper mining slaves in El Cobre, Cuba during the seventeenth and eighteenth centuries whose slaveholder had abandoned the area. Although slaves in law, they were not under any direct supervision, were left to support themselves through farming, hunting and mining, and were not compelled by violence of threat, or controlled by an employer; they were nevertheless socially and legally still considered slaves (O’Connell Davidson 2015, pp. 40-42). See also Diaz (2006).
} 
The notion of treating human beings as if they were objects - reducing people to things - is central to the understanding of enslavement, as explained through the lens of legal constructs of property law. Although noting the tensions and difficulties of the endeavour, Davis (1949, p 64) argues that it is the 'attempt to fit human beings into the category of objects of property rights' that makes slavery unique. This position found voice in South Africa's comment (League of Nations 1926b) expanding on the meaning of the definition of slavery contained in the League of Nations' 1925 Draft Slavery Convention to suggest that 'a person is a slave if any other person can, by law or enforceable custom, claim such property in him as would be claimed if he were an inanimate object'. The Sixth Committee likewise highlighted 'everything which admits the maintenance by a private individual of rights over another person of the same nature as the rights which an individual can have over things' as the subject of the prohibition against slavery and the slave trade (League of Nations 1926c, VI.B.5). Thus, the nucleus of de jure chattel slavery is the reduction of persons to the status of things in law. This reduction enables the denial of rights for enslaved people, both through the legal severance of enslaved persons from the legal rights of the general population, and the denial or degradation of human status. In the rhetoric of slavery, the reduction of human beings to sub-human status, or the treatment of them as such, has been both a strategy employed to justify and perpetuate the institution, and a feature of the phenomenon throughout history. The dehumanisation and 'othering' of individuals is therefore both strategic to, and an essential element of, chattel slavery.

In considering the machinery of enslavement through time, Finley (1998) speaks of the attribution of 'outsider status' as enabling and entrenching the practice, Patterson (1982, p 44) identifies the slave as outsider (both intrusively and extrusively conceived), and Lovejoy (2011) focuses on 'alien identity'. ${ }^{16}$ Brion Davis (2006, pp. 4864) similarly argues that slavery is based on patterns of marginalisation that denigrate 'outsider' peoples on the basis of assertions of barbarism, animalistic qualities, or a lesser degree of civilisation. The system of transatlantic chattel enslavement, like those systems of slavery that preceded and followed it, capitalised on negative characterisations of those subjected to enslavement to rationalise the treatment of those people. Through the centuries in which it developed and operated, the transatlantic system adapted prior emphasis on marginalisation to focus on a single factor (race) as the indicator of this range of characteristics (Sweet 1997). However, as an instrument of enslavement, racialisation served the function of dehumanisation and 'othering', rather than situating racial discrimination specifically as a prerequisite of slavery.

In a range of other historical slaveries, othering was not founded on race. In classical Greece, enslaved people typically came from Thrace (Southeast Europe), the Black Sea area, and eastern coast of the Aegean (Hunt 2017, p 31). Those enslaved in the Roman Empire generally came from the areas in which Romans were currently, or had previously, been fighting - covering virtually the whole of Europe, northern Africa, and the Near East at some point (Hunt 2017, p 31). Likewise, in the Northwest Coast culture area of indigenous North America, enslaved persons were typically war captives, and were commonly enslaved from neighbouring communities with shared language and culture (Donald 2011, p 230). In China, delineation of societal groups

\footnotetext{
${ }^{16}$ While Patterson also identifies 'natal alienation', the term is part of the composite definition of slavery posited, as opposed to alien identity as conceived by Lovejoy, which speaks to marginalisation and 'othering'.
} 
derived from pre-imperial times differentiated between 'common' and 'base' populations - the latter group being subjected to a distinctive (and more severe) legal regime, and the only persons that could be lawfully enslaved (Crossley 2011). Social class was inherited and inalienable, and 'base' people were typically born into their status. However, people might also decline to 'base' status (and therefore be subjected to enslavement) as 'prisoners of war, convicted criminals, of being identified as "idle" (Crossley 2011, p 189). This was not, however, delineated by race or ethnicity.

The dehumanisation needed to enable and justify the enslavement of people could be achieved in a variety of ways. Othering was achieved through the renaming, shaming, and labelling of enslaved persons, with their status and value entrenched in the discourse of the time. This is evidenced through the use of language to describe enslaved populations, from dehumanising labels characterising enslaved persons as 'nameless' and 'not human' in early modern China (Crossley 2011, p 190) and the denial of family names to those enslaved in ancient Near East (Mendelson 1949, p 31), to derogatory and racist epithets of 'negro', 'nigger', 'colored', and 'black' in the transatlantic system (Brown 2019, p 163). ${ }^{17}$ Visible markings and signifiers were also used to demarcate enslaved persons from the 'free' population, from tattoos in the ancient near East, branding in China, Hellenistic Egypt, Rome, Russia, and France, and special forms of clothing in Ashanti and Chinese slaveries (Patterson 1982, pp. 58-59), to absence of tribal markings (Little 1948, p 38), and special haircuts in the Northwest Coast of indigenous North America (Donald 2011, p 230). Enslaved persons' status as alien and 'sub-human' was also evidenced in the physical and psychological abuse they experienced (including their living conditions), and the denial of privacy, and dignity, which reflected their perceived worth.

Systems of de jure chattel slavery embedded othering in the law through legal discrimination between slaves and non-slaves. Enslaved persons in such systems were subjected to a distinctive legal regime that distinguished them from the 'free' population and denied them many of the legal rights afforded to 'free' people. In pre-imperial China enslaved people were forbidden from owning property, denied recognition of marriage and legitimacy of children (who were thereby enslaved), could not pursue legal action in court, and were restricted from acting as witnesses except in particular circumstances (Crossley 2011, p 191). In Visigoth kingdoms, enslaved persons could be tortured, were prohibited from marriage without the slaveholder's permission, could not initiate legal actions, and their testimony was invalid unless corroborated by the slaveholder (Phillips 1985, p 48; 2014, p 83). Bradley (2011, p 242) describes slavery in the Roman Republic as a 'state of complete non-being' in which persons enslaved lacked all rights and personhood. The Twelve Tables created lower penalties for injuries to enslaved persons (judging them to be inherently of lesser value than non-slaves), and more severe penalties for violations committed by enslaved persons (Bradley 2011, p 243).

\footnotetext{
${ }^{17}$ Alexander Brown also argues that such epithets were used as an instrument of enslavement.
} 
In many instances, differentiation between 'slaves' and 'non-slaves' in law was supported by forms of legal discrimination between different groups of people that justified their enslavement. Islamic Law, for instance, permitted the enslavement of non-Muslims (Freamon 2012; Ware 2011). Only legally categorised 'base' people in early modern China could be subject to enslavement (Crossley 2011). Transatlantic enslavement included the creation and enforcement of explicitly racialised legal mechanisms imposing sub-human status on people of African descent beyond the specific context of enslavement. Othering (alienation, marginalisation, and dehumanisation) remained the critical function of this differentiation, with the social construction of sub-human status reinforcing legal discrimination, and vice versa. Othering amplifies the chasm in power relations between enslaver and enslaved, and the marginalisation of the slave, inculcating a depreciation of the enslaved person's worth as a human being. This is both a mechanism of enslavement and a consequence.

Despite the attribution of sub-human status, the legal status of slavery was never as simplistic as the categorisation of enslaved persons as simply chattel in law to the exclusion of the recognition of their humanity - the laws of man had to recognise human status in ways that chattel could never hold status (Brion Davis 2006, p 36; Davis 1949, p 64). Even in the context of the system of transatlantic chattel slavery, ownership and possession of those enslaved was not absolute, and the dehumanisation of people was incomplete (see Tannenbaum 1992, p 8). While enslaved persons were classified as if they were things in the context of property law, other branches of law (as well as social and cultural practice) recognised them as persons. In criminal law, for instance, enslaved persons could be found guilty of committing a crime (a domain preserved for natural persons), despite not bearing rights to a defence in the courts convicting them of such offences. ${ }^{18}$ As the abolitionist William Goodell (1969, p 309) noted, "the slave becomes "a person" whenever he is to be punished!... He is under the control of law, though unprotected by law, and can know law only as an enemy, and not as a friend.'

Enslaved persons held a dual legal identity-simultaneously persons and things in the eyes of the law. Speaking in the context of ancient Greece and Rome, Westermann (1955, p 1) frames this as the 'constant paradox' of slavery 'inherent in the very nature of the institution', while Mendelsohn (1949, p 64) observes this legal tension in slavery in the ancient Near East. In pre-imperial China, legal documents described enslaved persons as 'half human and half thing' (Crossley 2011, p 191). Sio (1965, p 299) summarises the continuity of legal contestation in these contexts, noting that 'the slave had an ambiguous status: he was both an object of property rights and a rudimentary legal person.'

Protections afforded to enslaved persons (albeit limited) also implied recognition of their status as beings rather than things in particular contexts.

\footnotetext{
${ }^{18}$ For example, the Laws of Ur-Namma in third-millennium Mesopotamia and the laws of Early Iceland which provide penalties for various crimes committed by and against slaves. See respectively Verderame (2018) and Dennis et al. (1980). See also Article 31 of the French Code Noir (1685) which prohibited enslaved persons from being party as plaintiff or defendant in civil or criminal suits.
} 
Requirements or permissions for enslaved persons to be baptised or provided with religious instruction, ${ }^{19}$ protections against the worst abuses, punishments, and cruelties (even if rarely enforced), ${ }^{20}$ entitlements to compensation for harm caused to them by others, ${ }^{21}$ some appreciation of enslaved persons' rights (or at minimum, ability) to engage in commerce, ${ }^{22}$ and limited recognition of rights relating to marriage and family life $^{23}$ all acknowledge a degree of humanity, agency, or subjecthood beyond that of chattels. In some instances, enslaved persons were permitted to report to the court and provide testimony. ${ }^{24}$ Even the restraints and prohibitions contained in the infamous slave codes affirm the need to regulate the actions of enslaved persons as actors, and not just as things owned. ${ }^{25}$ Likewise, the possibility of manumission, even when not a legal right or guarantee, rendered the chattel status of enslaved persons a metaphor rather than a reality. Manumitted and emancipated slaves became free people, where previously they had been unfree people, making manumission or emancipation a change in status rather than state. As Tannenbaum (1992, p 8) highlights, the possibility for manumission and 'gradual achievement of freedom' entails recognition of moral personality. Although enslaved persons were treated as property, and the powers associated with

\footnotetext{
${ }^{19}$ Article 2 of the French Code Noir (1685) required slaves be baptised in the Roman Catholic Church while article 3 provided for the punishment of enslavers who publicly practiced other religions. Article 2 of Jamaica's 1816 law likewise demanded religious instruction and baptism for slaves. The 1705 Virginia Slave Code, on the other hand, recognised that enslaved persons might be baptised, but declared that this would not exempt them from enslavement, article 36.

${ }^{20}$ Islamic law entitled enslaved people to the protections of homicide law (Freamon 2012, p 50). In early modern China, women kept enslaved in a household were subject to 'normal familial rules of incest and avoidance', albeit applying in the event that enslaved woman had been 'sexually dominated by the father of the house' (Crossley 2011, p 194). The second Khan and first Qing emperor in China (1627-1643) established rules imposing punishment for beating, raping, starving, and mistreatment of slaves (Crossley 2011, p 202). Article 42 of the French Code Noir (1685) prohibited torture and mutilation, article 43 killing enslaved persons, and article 40 falsely accusing an enslaved person of a crime and having them put to death, while articles 22-27 require masters provided enslaved persons under their control with food and clothing. See also The Barbados Slave Code (1661); Jamaica's Slave Code (1816).

${ }^{21}$ Such as in Early Icelandic laws. The Wergild Ring List sets out the laws on compensation, and includes where a slave was struck by another master's slave, the perpetrator was required to pay compensation to the master, and if he could do so, also to the slave (Code K.III). See Dennis et al. (1980).

${ }^{22}$ Articles 18-21 of the French Code Noir (1685); article 15 of the Virginia Slave Code (1705).

${ }^{23}$ For instance, Islamic law recognised the special status of 'concubines' who gave birth to their 'owner's' children, making the children free at birth and equal to the father's other children, and emancipating the concubine by law upon the death of her 'owner' (Freamon 2012, p 42). It likewise allowed for marriages between enslaved and free people, contrasting with previous Hindu law that declared that marriage to an enslaved person would result in the enslavement of the free partner. See also the medieval law code of Valencia, the Furs, which provided that where slaves gave birth to their slaveholders' child, both slave and child were required to be set free, or the slave could take the slaveholder to court if the law was not observed (Phillips 2014, p 29). The French Code Noir (1685), articles 10 and 11 in relation to marriage between enslaved persons, articles 9 and 13 relating to children born between free and enslaved persons, and article 47 preventing an enslaved husband, wife, and prepubescent children from being sold separately.

${ }^{24}$ In China's Qing dynasty, enslaved persons were permitted to report to the court specifically on treasonous acts committed by their masters, and were rewarded with 'money, silk, sables, and, of course, slaves of their own' for doing so (Crossley 2011, p 202). Where the master was not convicted, however, the enslaved person would be subjected to death by strangulation (p 191).

${ }^{25}$ See article 10 and 16 of the French Code Noir (1685); the Barbados Slave Code (1661); articles 19-20, 32 of Virginia's Slave Code (1705).
} 
ownership were exercised over them while enslaved, they simultaneously held a legal status separate from chattel property that affirmed at least a degree of human 'being'. 26

The presentation of freedom and liberty as the antithesis of slavery is at the core of global understandings of slavery through the nineteenth and twentieth centuries. Abolitionist rhetoric often presented slavery as critical affront to these increasingly fundamental ideals, which connected antislavery advocacy to burgeoning republican movements in a variety of contexts (Brion Davis 1999; Diggins 1976; Dubois 2006; Roberts 2013). Islamic law went so far as to declare 'freedom' to be 'nothing more than the absence of slavery' (Freamon 2012, p 41). Yet, like the deprivation of legal identity and personhood, the relationship between slavery and freedom cannot be regarded as a binary, either in the context of de jure chattel slavery or de facto slavery. In practice, elements of freedom have existed in various systems and instances of chattel slavery throughout history, sometimes providing levels of freedom for persons with slave status comparable to those enjoyed by non-slave groups (see Craven and Hay 1994). For instance, the choris oikountes of classical Greece paid monthly dues to their 'masters' but otherwise lived apart from them and were not regularly subjected to their commands (Hunt 2017, p 19). However, their 'masters' continued to hold a proprietary relationship over the choris oikountes, retaining the ability to sell them at any time, for any purpose. Historical accounts also describe how persons enslaved in nineteenth century North America were permitted to run small enterprises that enabled the establishment of skills and businesses, which in turn led to economic freedom both during and following enslavement (Nicholson 2018). This runs counter to the argument of scholars who suggest that the construction of slavery as a category creates a binary (for instance, O’Connell Davidson 2010).

'Freedom' for non-slaves has been far from absolute in many contexts, with personal and impersonal forces impinging upon personal liberty in a variety of ways (see O’Connell Davidson 2015; Landman 2018; Choi-Fitzpatrick 2017). People not legally classified as 'slaves' but held in serfdom, debt bondage, servile marriage, indentured servitude, or other forms of servile labour, although not suffering the legal death of slavery so defined, could be held in conditions almost indistinguishable from chattel slavery in every other respect, as well as potentially experiencing some incursions on their legal status (see Lott 1998). As Miers (2000, p 715) highlights, 'chattel slavery is at one end of a continuum on the other end of which is "freedom". [...] Between these extremes are practices that are different from chattel slavery, but have some of its features and may be just as cruel or exploitative.'

Landman (2018, p 148) therefore presents the relationship between slavery, agency, and free labour as a continuum, accounting for forces operating on the macro as well as micro level. At some point along this spectrum, denial of agency and unfreedom of labour become slavery - characterised as the most severe form of deprivation. This does not, as O'Connell Davidson suggests, necessitate a conclusion that anything not

\footnotetext{
${ }^{26}$ In Roman law, this was captured in the recognition of slavery as an element of ius gentium (the laws of man) that breached ius naturale (the laws of nature) because all men were equal under law. The premise of this formulation being that those enslaved were also 'men' and equals in the law of nature - (Sio 1965, p 293).
} 
meeting the threshold of slavery is therefore considered 'appropriate exploitation'. ${ }^{27}$ Just as international and domestic legal frameworks recognise various forms of 'inappropriate' exploitation, not all of which are categorised as slavery, affirmation of the existence of either de jure or de facto slavery does not preclude recognition of other illegitimate forms of human exploitation and abuse. Lott (1998) captures this relationship between slavery and other forms of exploitation considered along a continuum, noting that slavery 'has always stood at one pole of a continuum of exploitation, shading off into servitude and other forms of exploitation, rather than existing as a wholly distinct, isolated phenomenon'. ${ }^{28}$ These tensions highlight the ambiguities of de jure slavery, bringing the phenomenon closer to the complexity and incomplete dehumanisation of de facto slavery than is often presumed.

\section{Is there a Fundamental Difference Between De Jure and De Facto Slavery?}

The paradigm of de jure chattel slavery prima facie admits the construction of a slave/ non-slave binary on the basis of legal status - either a person is held as property according to the law, or they are not. However, this binary holds only for the question of legal status, and consideration of the condition and experience of enslavement (even in the context of de jure chattel slavery) necessitates a more complex formulation. From an abolitionist perspective, such an approach is required to prevent the continuation of the behaviours constituting de jure chattel slavery under new legal classifications. In the most extreme cases, the manifestations of 'slavery by other names' might engage the machinery of the State in upholding a discriminatory system of exploitation in a functionally analogous manner as in a system of de jure chattel slavery. For instance, drawing lessons from colonial practices in the nineteenth and early twentieth century (Mazower 2008), and founded on extreme othering of particular groups of people in order to justify abuse and exploitation (Stone 2017, p 12), Nazi-forced labour camps in WWII embedded a condition of total domination in exploitation within legal frameworks. ${ }^{29}$ Yet, despite the totality of control, arbitrariness and discriminatory premise of detention, extreme levels of abuse, and permanence of the condition, dominant narratives continued to frame exploitation in these contexts as 'forced labour' rather than slavery (Schwarz 2020). Recognition of these practices as slave labour (as constructed in the crime against humanity of enslavement in the Nuremberg Trials) requires acceptance of the possibility for slavery to exist as a condition or experience rather than a legal status. Conversely, defining the boundaries of slavery without a frame of reference beyond legal status creates an absurdity in the definition: that States might

\footnotetext{
${ }^{27}$ O'Connell Davidson argues that this is the necessary conclusion of recognising slavery - that slavery is classed as 'inappropriate exploitation' and all other forms of exploitation are thereby categorised as 'appropriate'-(O’Connell Davidson 2010, p 249; 2006, 2015).

${ }^{28}$ Even continuum characterisations should be approached with some caution, as they risk conflating questions of degree (whether of freedom, exploitation, or abuse) with categorical questions concerning the type of experience and relationship embodied. Slavery is here conceived as a particular kind of experience and relationship, rather than simply as the extreme end of a simple continuum of behaviour.

${ }^{29}$ It should be noted that, like the system of transatlantic enslavement which manifested in a broader system of abuse - the maangamizi - this exploitation (slavery) occurred in the context of a broader set of abuses and violations against particular groups of people.
} 
create discriminatory systems of exploitation involving total and permanent control over people as if they were things, upheld by the legal machinery of the State, ${ }^{30}$ which could be constructed as non-slavery simply by labelling them as such.

The conceptual clarity of de jure chattel slavery relies upon the legal classification of a person as property. The determination of whether a person is enslaved turns on the question of status, rather than considering the nature of the condition in which that person is enslaved. In other words, slavery is defined by legal categorisation and not by particular characteristics or behaviours inflicted upon the person enslaved. The line drawn by the law then is not between levels of freedom or unfreedom, the exercise of property rights in fact, or concerns of power, agency, and liberty, but simply on whether the legal frameworks in place recognise legal ownership of persons on paper. However, in the translation of law to practice, the clarity obtained by adhering to this definition radically degrades. The legal status created within systems of de jure chattel slavery involves treating a person as if they were a thing and legally classifying them as such. In this paradigm, it is possible for an individual to be legally enslaved but virtually free in practice. ${ }^{31}$ Slavery on this understanding is not 'social death' as Patterson (1982) explains it, but legal death. Chattel slave status usurped legal personality (at least to a certain degree), instead ascribing the legal status of a thing to the person enslaved. This reflects historical legal justifications for enslavement as an alternative to death (Schwarz 2019; Allain 2012). Yet, as discussed in part II above, this alienation of legal personality did not need to be absolute to create a relationship of legal ownership, and in practice legal status often defied binary categorisation as either person or chattel.

In practice, legal personality exists on a spectrum rather than as a binary, and practices involving the treatment of persons as commodities not founded on legal recognition of ownership could nonetheless involve abrogation of legal personality. The potential for such diminution of legal identity was recognised by the International Criminal Tribunal for the Former Yugoslavia in the Kunarac case (2002, para 117), noting that:

In the case of these various contemporary forms of slavery, the victim is not subject to the exercise of the more extreme rights of ownership associated with "chattel slavery", but in all cases, as a result of the exercise of any or all of the powers attaching to the right of ownership, there is some destruction of the juridical personality; the destruction is greater in the case of "chattel slavery" but the difference is one of degree.

The Inter-American Court of Human Rights likewise recognised this effect of the exercise of the powers attaching to the right of ownership in practice, rather than law, highlighting that the impact of these powers was 'that the enslaver exercises power or control over the enslaved person to the point of nullifying the victim's personality' (Case of the Hacienda Brasil Verde 2016, para 269).

\footnotetext{
${ }^{30}$ This might be achieved, for instance, by positioning and enforcing State power through other legal mechanisms than property law and rights of ownership.

${ }^{31}$ See, for instance, the example of 'copper mining slaves' in El Cobre-(O'Connell Davidson 2015, pp. 40-42).
} 
De jure slavery employs legal machinery to create and enforce a slave status that enables, perpetuates, and justifies the treatment of people as property. However, Patterson (1982, pp. 21-22) highlights the limitations of reliance on the legal property paradigm, noting the difficulty of defining slavery by a notion of property rights over others that does not differentiate between categories of property or the objects of property relations. Instead, he defines property as 'claims and powers vis-a-vis other persons with respect to a given thing, person, or action' irrespective of whether they are situated in property law. This relationship may be institutionalised through legal frameworks, but might also be created and upheld through equivalent customary or social norms and authorities. De jure slavery then entails a relationship of domination both between the person enslaved and their enslaver, and also between the person enslaved and the State (or other authority). As O'Connell Davidson (2017, p 2) highlights, slavery in this context is 'more than simply a relationship between individuals', it is a 'status ascribed by the state'. This official recognition and maintenance of slavery has both symbolic and practical implications. Law both reflects and reshapes society, acting as a moral and cultural signifier to shape and change social norms (see Sunstein 1996, 1999).

In the context of de jure slavery, the law endorses and reinforces the dehumanisation of those enslaved, providing a patina of legitimacy to the treatment of those people as sub-human that has the potential to influence social and cultural norms. The legality of slavery thus contributes to othering of these peoples that occurs in non-legal spheres. However, law is not the only mechanism for such social and cultural signalling, and the result may be achieved absent support from legal machinery. Where legal ownership was the empowering frame for the use and abuse of enslaved persons in ways not permitted (socially and legally) for the general population, the exercise of symbolic power - the recognition of the legitimacy of powers of ownership absent legal ownership of the person - reveals a parallel in the experiences of those enslaved in de facto contexts. Law as power is not in itself authoritative. Obedience often occurs for reasons that have nothing to do with the existence of law alone, so that law is 'merely a shadow' (Raz 1984, p 141) of, inter alia, social mores, feelings of duty, and individual interests. Thus, social and cultural norms, as well as other behaviours not backed by legal frameworks, might stand in for the law in creating and reinforcing the wider societal power dynamics of slavery.

As well as providing official endorsement, the law in systems of de jure chattel slavery enforces the subjection of people to slavery. The legal status of slavery enables the use of the mechanisms of property law to subject, hold, and return people to enslavement, as well as the framework of criminal law to punish them should they resist. This distinguishes situations of de jure slavery from potential or claimed situations of de facto slavery, as it is not only the power of the private individual enslaver that is exercised to maintain a person in slavery, but the legal machinery of the State. Yet, in many slave societies, no formal systems of law existed, with violence, corporeal possession, and extreme power over others being more definitive of slave/ master relations (Patterson 2012, p 331). Where authority is institutionalised in this way, slavery does not necessarily need the law to be legitimised. Instead, it is institutionalised within and by geographic, cultural, and criminal 'communities', whether this be within the 'community' of the State, locale, or within a group of people. Even absent legal recognition of de jure slavery, the State may itself perpetrate 
slavery, or provide the conditions for the perpetration of slavery within its borders with impunity. Further, a country's culture may not recognise particular cultural practices as potential forms of slavery, creating an environment that renders enslavement permissible within the confines of certain parameters. In such circumstances, these actors create conditions for local or regional acceptance of ongoing practices.

Where official actors are corrupt, complicit, or apathetic towards slavery practices occurring within their boundaries, the effect is to legitimise slavery and create the conditions to disempower those enslaved (de facto slavery). Even where slavery has been legally prohibited, those who disobey may have little fear of sanction, whether as a result of official complicity or corruption. ${ }^{32}$ Thus, for many enslavers, the consequences of violation are outweighed by personal interest. This precludes the operation of justice mechanisms as a protective framework for people who experience enslavement in practice, shutting those enslaved out of judicial processes to redress violations in a functionally similar manner as if they were legally excluded. Contemporary examples of powers exercised in this way include testimony reflecting corrupt law enforcement officials who 'rescue' those in forced sexual exploitation in order to re-sell them (see Bales and Trodd 2008, pp. 117-118). It is also evidenced in the pervasiveness of Restavec child domestic exploitation in Haiti (see Cadet 1998), the Trokosi system (see Bales and Trodd 2008, p 68), hereditary slavery in Mauritania (Bales and Trodd 2008, p 225), and forced sexual exploitation perpetrated by ISIS (Khalaf and Hoffmann 2016; Al-Dayal et al. 2020). The exercise of power and the creation of unequal power relations is not premised solely on exploitation, but also on the social marginalisation of specific groups and the widespread employment of state-like force and power, such as with state-imposed forms of slavery existing in prison camps (see U.S. House 2005).

The legitimacy of the slaveholders' domination therefore need not simply rest on the law. It also rests (and rested) on the institution's acceptance, the prevalence of practices and treatment of certain groups (minorities, ethnicities, caste, gender) in society, and in the displacement of individuals from family, culture, and ancestry, such that those enslaved have 'no legitimate, independent being, no place in the cosmos except as the instrument of her or his master's will' and no power upon which to alter their circumstances (Brion Davis 2006, p 31). In many contemporary cases, the illicit nature of slavery means individuals are isolated, narrowing their physical and emotional environment (for example as a result of removal to an alien country or culture, indoctrination, branding, or through physical isolation). This isolation creates an environment akin to a closed society that enforces an internal normative acceptance of their enslavement. Examples can be seen in enslavement perpetuated by smaller groups or individuals, such as that perpetrated by powerful local gangs who are able to purchase impunity and silence, both financially and socially, as a result of their dominance in the locale (see Bales and Trodd 2008, pp. 90-102).

Prioritising the power relationship as the frame for 'the exercise of any or all of the powers of ownership', rather than a focus exclusively on the usual language of control, offers a useful lens to understand how the status of slavery translates to a condition. The power relation is not here conceptualised as merely existing between the individual slaveholder and the enslaved, but accounts for the layered levels at which the levers of power are exercised, and the powers alienated from the enslaved person as a result (see

\footnotetext{
$\overline{32}$ On theories of compliance with law concerned with other social and criminological factors, see Raz (1984).
} 
Landman 2018). Where law provides one source of authority for slavery, the power relation between the enslaved and a variety of other actors and factors also provide frameworks of authority, including the role of the State, society, culture, community, and the relative economic and structural power (or lack thereof) available to those enslaved.

\section{Conclusion}

Until recently, much of the academic analysis of slavery positioned the transatlantic system as the paradigm. This approach risks overlooking the diversity of historical slaveries that have existed in different geographies throughout human history. It also fails to respect the voices of people of African descent who continue to experience the legacies of racialised chattel enslavement today (INOSAAR 2017; Karenga 2001), by distilling the maangamizi down to slavery alone. Moving beyond this paradigm requires a new starting point for conceptualising slavery in a landscape of significant contestation and debate. As a widely accepted archetype, de jure chattel slavery provides a solid foundation for considering the features and contours of slavery. Taking this uncontested form of slavery as a starting point enables exploration of the core features of slavery, and reconsideration of the role and necessity of legal status in constituting these elements.

Unpacking the framework of property rights in persons manifested in de jure chattel slavery reveals the core elements in the relationship of ownership that underpins these rights - namely control exercised over a person as if they were a thing, tantamount to possession. The perceived permanence and totality of the condition of slavery are core to this property frame, associated with absolute command over the person as a whole and a resultant lack of futurity. Othering (through the marginalisation, denigration, and alienation of people from the free community) remains a central element, both as a mechanism for enslavement and as a consequence. Differentiation and attribution of sub-human status in law permits violent domination, frequently manifesting in severe and horrific abuses against persons enslaved. Yet it is the potential for such violations - the permission created by law or equivalent authority - rather than the exercise of such that is definitive of slavery. These power relations of slavery may be upheld in a variety of ways, both legal and extra-legal, to facilitate the treatment of persons as if they were things, and enable their exploitation. In this relationship, control is not merely exercised by the enslaver, but alienated from the person enslaved. It is legal status that provides the label of slavery in the context of de jure chattel slavery, but it is not only legal status that creates, upholds, permits, and justifies enslavement in these cases. The lack of parity between de jure and de facto slavery is thus less substantial than is often presumed.

Recognition that the legitimisation of de jure chattel slavery manifests through the exercise of power in non-legal ways indicates that there is no definitive difference between de jure and de facto slavery. This does not imply that all severe forms of human exploitation constitute slavery, nor does it establish the boundaries between de facto slavery and other forms of exploitation. However, it does deconstruct the presumed boundaries between de jure and de facto slavery. It examines parallel experiences of the elements of de jure chattel slavery identified in part II in situations 
in which legal ownership of persons is not recognised-conditions that manifest the relationship of ownership, whether in law or in fact. This entails recognition of the potential for practices not labelled as slavery in law to be slavery in fact, and provides a solid foundation for reconsidering the outer parameters of slavery in light of the experiences at its centre.

Rather than presenting the legal label as determinative, or accepting a broad spectrum of different practices within the umbrella of slavery, this approach defines the contours of slavery by reference to the core attributes of the institution. It looks beyond the transatlantic paradigm, acknowledging the broader history of slavery and the maangamizi, to construct an understanding of slavery as a condition as well as a status. The consequence of this is to reset the foundations for conceptualising slavery, accounting for both historical continuities and critical perspectives and collapsing the boundaries between de jure and de facto slavery.

Acknowledgements This work was supported by Arts and Humanities Research Council and Economic and Social Research Council grant Modern Slavery: Meaning and Measurement [grant number ES/P001491/1] (PaCCS Transnational Organised Crime, University of Nottingham, 2016-18). The authors would like to thank Todd Landman and Helen McCabe for insightful feedback on a draft version.

Open Access This article is licensed under a Creative Commons Attribution 4.0 International License, which permits use, sharing, adaptation, distribution and reproduction in any medium or format, as long as you give appropriate credit to the original author(s) and the source, provide a link to the Creative Commons licence, and indicate if changes were made. The images or other third party material in this article are included in the article's Creative Commons licence, unless indicated otherwise in a credit line to the material. If material is not included in the article's Creative Commons licence and your intended use is not permitted by statutory regulation or exceeds the permitted use, you will need to obtain permission directly from the copyright holder. To view a copy of this licence, visit http://creativecommons.org/licenses/by/4.0/.

\section{References}

Al-Dayel N, Mumford A, Bales K (2020) Not Yet Dead: The Establishment and Regulation of Slavery by the Islamic State. Studies in Conflict \& Terrorism: 1-24.

Allain J (2008) The Slavery Conventions: The Travaux Préparatoires of the 1926 League of Nations Convention and the 1956 United Nations Convention. Martinus Nijhoff, Leiden.

Allain J (2012) Slavery in International Law: Of Human Exploitation and Trafficking. Martinus Nijhoff, Leiden.

Allain J (2019) Slavery and Its Obligations Erga Omnes. The Australian Year Book of International Law 36(1): 85-124.

Allain J, Hickey R (2012) Property and the Definition of Slavery. International and Comparative Law Quarterly 61(4): 915-938.

Austen RA (1977) Slavery among the Coastal Middlemen: The Duala of the Cameroon. In: Miers S, Kopytoff I (eds) Slavery in Africa: Historical and Anthropological Perspectives. University of Wisconsin Press, Wisconsin.

Bales K (2005) Understanding Global Slavery: A Reader. University of California Press, Berkeley.

Bales K, Trodd Z (2008) To Plead Our Own Cause: Personal Stories by Today's Slaves. Cornell University Press, Ithaca.

Beutin LP (2017) Black Suffering for/from Anti-trafficking Advocacy. Anti-Trafficking Review 9: 14-30.

Blackstone W (1765) Commentaries on the Laws of England, Book 2.

Blight D (2009) A Slave No more, Two Men Who Escaped to Freedom, Including Their Own Narratives of Emancipation. Mariner Books, New York. 
Bradley K (2011) Slavery in the Roman Republic. In: Bradley K, Cartledge P (eds) The Cambridge World History of Slavery: The Ancient Mediterranean World, vol 1. Cambridge, Cambridge University Press, pp. 241-264.

Bravo K (2011) The Role of the Transatlantic Slave Trade in Contemporary Anti-Human Trafficking Discourse. Seattle Journal for Social Justice 9(1): 555-597.

Brion Davis D (1999) The Problem of Slavery in the Age of Revolution, 1770-1823, reprint. Oxford University Press, Oxford.

Brion Davis D (2006) Inhuman Bondage: The Rise and Fall of Slavery in the New World. Oxford University Press, Oxford.

Brown A (2019) African Enslavement, Speech Act Theory, and Law. Journal of African American Studies 23: $162-177$.

Braund D (2011) The Slave Supply in Classical Greece. In: Bradley K (ed) The Cambridge World History of Slavery: The Ancient Mediterranean World, vol 1. Cambridge University Press, Cambridge.

Cadet JR (1998) Restavec: From Haitian Slave Child to Middle Class American. University of Texas Press, Austin.

Choi-Fitzpatrick A (2017) What Slaveholders Think: How Contemporary Perpetrators Rationalize What They Do. Columbia University Press, New York.

Chuang J (2014) Exploitation Creep and the Unmaking of Human Trafficking Law. The American Journal of International Law 108(4): 609-649.

Chuang J (2015) The Challenges and Perils of Reframing Trafficking as "Modern-Day Slavery". AntiTrafficking Review 5: 146-149.

Craven P, Hay D (1994) The Criminalization of "Free" Labour: Master and Servant in Comparative Perspective. Slavery \& Abolition 15(2): 71-101.

Crossley PK (2011) Slavery in Early Modern China. In: Eltis D, Engerman SL (eds) The Cambridge World History of Slavery, vol 3. Cambridge University Press, Cambridge, pp. 186-214.

D’Anjou L, Van Male J (1998) Between Old and New: Social Movements and Cultural Change. Mobilization: An International Quarterly 3(2): 207-226.

Davis K (1949) Human Society. The MacMillan Company, New York.

Dennis A, Foot P, Perkins R (trans) (1980) Laws of Early Iceland, Grágás. The Codus regius of Grágás, with Material From Other Manuscripts. University of Manitoba Press, Winnipeg

Diaz ME (2006) Mining Women, Royal Slaves: Copper Mining in Colonial Cuba 1670-1780. In: Mercier L, Viskovatoff J (eds) Mining Women: Gender in the Development of a Global Industry, 1700 to 2000. Palgrave Macmillan Press, London.

Diggins JP (1976) Slavery, Race, and Equality: Jefferson and the Pathos of Enlightenment. American Quarterly 28: 206-228.

Dockès P (1982) Medieval Slavery and Liberation, translated by A Goldhammer. University of Chicago Press, Chicago.

Documenting the American South (n.d.) https://docsouth.unc.edu Accessed 14 May 2020

Donald L (2011) Slavery in Indigenous North America. In: Eltis D, Engerman SL (eds) The Cambridge World History of Slavery, vol 3. Cambridge University Press, Cambridge, pp. 217-247.

Dubois L (2006) An Enslaved Enlightenment: Rethinking the Intellectual History of the French Atlantic. Social History 31(1): 1-14.

Elkins S (1959) Slavery: A Problem in American Institutional and Intellectual Life. University of Chicago Press, Chicago.

Eltis D, Engerman S (2011) Dependence, Servility, and Coerced Labour. In: Eltis D, Engerman S (eds) The Cambridge World History of Slavery, vol 3. Cambridge University Press, Cambridge.

Finley M (1998) Ancient Slavery and Modern Ideology. Markus Wiener, Princeton.

Fisher N (1993) Slavery in Classical Greece. Bristol Classical Press, Bristol.

Freamon B (2012) Definitions and Conceptions of Slave Ownership in Islamic Law. In: Allain J (ed) The Legal Understanding of Slavery: From the Historical to the Contemporary. Oxford University Press, Oxford.

Gifford A (2007) Pipe Dream or Necessary Atonement. Index on Censorship 36: 89-96.

Glancy J (2002) Slavery in Early Christianity. Oxford University Press, Oxford.

Goodell W (1969) The American Slave Code in Theory and Practice: Its Distinctive Features Shown by its Statutes, Judicial Decisions and Illustrative Facts. Negro Universities Press, New York.

Goody J (1980) Slavery in Time and Space. In: Watson J (ed) Asian and African Systems of Slavery. University of California Press, Berkeley.

Heuman G, Burnard T (2011) The Routledge History of Slavery. Routledge, Abingdon. 
Hickey R (2012) Seeking to Understand the Definition of Slavery. In: Allain J (ed) The Legal Understanding of Slavery: From the Historical to the Contemporary. Oxford University Press, Oxford.

Hunt P (2017) Ancient Greek and Roman Slavery. John Wiley \& Sons, Hoboken.

INOSAAR (2017) Public Report: Launch of the International Network of Scholars and Activists for Afrikan Reparations. INOSAAR. www.inosaar.llc.ed.ac.uk/sites/default/files/atoms/files/public_report_21_ oct 2017.pdf Accessed 13 May 2020

International Labour Organisation and Walk Free Foundation (2017) Global Estimates of Modern Slavery. International Labour Organisation. https:/www.ilo.org/global/publications/books/WCMS_575479 /lang\%2D\%2Den/index.htm Accessed 1 June 2020

Jackson BS (2006) Slavery. In: Wisdom Laws: A Study of the Mishpatim of Exodus 21:1-22:16. Oxford University Press, Oxford, pp. 78-119.

Joshel S (2010) Slavery in the Roman World. Cambridge University Press, Cambridge.

Karenga M (2001) The Ethics of Reparations: Engaging the Holocaust of Enslavement. www.ncobraonline. org/wp-content/uploads/2016/02/Karenga-THE-ETHICS-OF-REPARATIONS.pdf Accessed 13 May 2020

Khalaf F, Hoffmann AC (2016) The Girl Who Beat Isis: My Story. Vintage Digital, New York.

Kurasawa F (2014) The Long Shadow of History: The Paradoxes of Iconographic Reiteration in Anti-slavery Advocacy. American Journal of Cultural Sociology 2(1): 3-32.

Laccino L (2016) Stop the Maangamizi: Africans "Never Received Even an Apology for Slavery”. IB Times. www.ibtimes.co.uk/stop-maangamizi-africans-never-received-even-apology-slavery-1573817 Accessed 15 May 2020

Landman T (2018) Out of the Shadows: Trans-disciplinary Research on Modern Slavery. Peace Human Rights Governance 2(2): 143-162.

Little K (1948) The Mende Farming Household. Sociological Review 40(4): 37-56.

Lott T (1998) Subjugation and Bondage: Critical Essays on Slavery and Social Philosophy. Rowman \& Littlefield, Lanham.

Lovejoy P (2011) Transformations in Slavery: A History of Slavery in Africa. Cambridge University Press, Cambridge.

Mazower M (2008) Hitler's Empire: How the Nazis Ruled Europe. Penguin, London.

McKeown N (2010) Greek and Roman Slavery. In: Heuman G, Burnard T (eds) The Routledge History of Slavery. Routledge, Abingdon.

Mendelsohn I (1949) Slavery in the Ancient Near East: A Comparative Study of Slavery in Babylonia, Assyria, Syria, and Palestine, from the Middle of the Third Millennium to the End of the First Millennium. Oxford University Press, Oxford.

Miers S (2000) Contemporary Forms of Slavery. Canadian Journal of African Studies 34(3): 714-747.

Miller J (2008) Slaving as an Historical Process: Examples from the Ancient Mediterranean and the Modern Atlantic. In: Dal Lago E and Katsari C (eds) Slave Systems: Ancient and Modern. Cambridge University Press, Cambridge.

Nicholas B (1976) An Introduction to Roman Law, revised edn. Oxford University Press, Oxford.

Nicholson A (2018) Bearing Witness: Contemporary Slave Narratives and the Global Antislavery Movement. $\mathrm{PhD}$ Thesis, University of Nottingham.

Nicholson A, Dang M, Trodd Z (2018) A Full Freedom: Contemporary Survivors' Definitions of Slavery. Human Rights Law Review 18(4): 689-704.

Nieboer H (1971) Slavery as an Industrial System: Ethnological Research 2nd revised edn. B Franklin, New York.

O’Connell Davidson J (2006) Will the Real Sex Slave Please Stand Up? Feminist Review 83: 4-22.

O'Connell Davidson J (2010) New Slavery, Old Binaries: Human Trafficking and the Borders of "Freedom". Global Networks 10(2): 244-261.

O'Connell Davidson J (2015) Modern Slavery: The Margins of Freedom. Palgrave Macmillan, London.

O'Connell Davidson J (2017) Editorial: The Presence of the Past: Lessons of History for Anti-Trafficking Work. Anti-Trafficking Review 9: 1-12.

Patterson O (1982) Slavery and Social Death: A Comparative Study. Harvard University Press, Cambridge.

Patterson O (2018) Slavery and Social Death: A Comparative Study, with New Preface. Harvard University Press, Cambridge.

Patterson O (2012) Trafficking, Gender and Slavery: Past and Present. In: Allain J (ed) The Legal Understanding of Slavery: From the Historical to the Contemporary. Oxford University Press, Oxford.

Penner JE (1997) The Idea of Property in Law. Clarendon Press, Oxford.

Penner JE (2012) The Concept of Property and the Concept of Slavery. In: Allain J (ed) The Legal Understanding of Slavery: From the Historical to the Contemporary. Oxford University Press, Oxford. 
Pierre B (1997) Classification of Property and Conceptions of Ownership in Civil and Common Law. Revue Générale de Droit 28(2): 235-274.

Phillips WD (1985) Slavery from Roman Times to the Early Transatlantic Trade. Manchester University Press, Manchester.

Phillips WD (2014) Slavery in Medieval and Early Modern Iberia. University of Pennsylvania Press, Philadelphia.

Pulleyblank EG (1958) The Origins and Nature of Chattel Slavery in China. Journal of the Economic and Social History of the Orient 1(2): 185-220.

Quirk J (2008) Unfinished Business: A Comparative Study of Historical and Contemporary Slavery. UNESCO. http://www.unesco.org/culture/pdf/UnfinishedBusinessReport2008.pdf Accessed 01 June 2020

Quirk J (2011) The Anti-slavery Project: From the Slave Trade to Human Trafficking. University of Pennsylvania Press, Philadelphia.

Raz J (1984) The Obligation to Obey: Revision and Tradition. Notre Dame Journal of Law, Ethics \& Public Policy 1: 139-155.

Reid A (1983) Slavery, Bondage and Dependency in Southeast Asia. University of Queensland Press, Brisbane.

Research Group on the Legal Parameters of Slavery (2012) Bellagio-Harvard Guidelines on the Legal Parameters of Slavery. https:/glc.yale.edu/sites/default/files/pdf/the_bellagio-_harvard_guidelines_on_ the legal parameters_of_slavery.pdf Accessed 1 June 2020

Roberts J (2013) Slavery and the Enlightenment in the British Atlantic, 1750-1807. Cambridge University Press, Cambridge

Schwarz K (2019) Reconceiving Reparatory Justice: Transatlantic Enslavement, the Maangamizi, and the Making of International Law. PhD thesis, University of Nottingham

Schwarz K (2020) Definitions and Ideologies of Slavery and Trafficking. In: Altnick H (ed) Cultural History of Slavery and Human Trafficking: Global Conflict, Colonialism, and Decolonisation 1900-1945. Bloomsbury Academic, London.

Sio AA (1965) Interpretations of Slavery: The Slave Status in the Americas. Comparative Studies in Society and History 7(3): 289-308.

Smith MG (1954) Slavery and Emancipation in Two Societies. Social and Economic Studies 3(3): 239-290.

Snell D (2011) Slavery in the Ancient Near East. In: Bradley K (ed) The Cambridge World History of Slavery: The Ancient Mediterranean World, vol 1. Cambridge University Press, Cambridge.

Snow DA, Benford RD (1992) Master Frames and Cycles of Protest. In: Morris AD, McClurg Mueller C (eds) Frontiers in Social Movement Theory. Yale University Press, New Haven, pp. 133-155.

Stampp K. (1956) The Peculiar Institution: Slavery in the Ante-Bellum South. Alfred A. Knopf, New York.

Stanford-Xosei E (2015) What is the International Social Movement for Afrikan Reparations (ISMAR)? Reparations Scholar-Activist. reparationsscholaractivist.wordpress.com/2015/02/20/what-is-the-ismar/ Accessed 15 May 2020

Stone D (2017) Concentration Camps: A Short History. Oxford University Press, Oxford.

Sunstein CR (1996) On the Expressive Function of Law. University of Pennsylvania Law Review 144: 20212053.

Sunstein CR (1999) Law's Expressive Function. The Good Society 9(2): 55-61.

Sweet J (1997) The Iberian Roots of American Racist Thought. William and Mary Quarterly 54: 143-166.

Tannenbaum F (1992) Slave and Citizen, reprint. Beacon Press, Boston.

Trodd Z (2013) Am I Still Not a Man and A Brother? Protest Memory in Contemporary Antislavery Visual Culture. Slavery and Abolition 34(2): 338-352.

Verderame Lorenzo (2018) Slavery in Third-Millenium Mesopotamia: An Overview of Sources and Studies. Journal of Global Slavery 3: 13-40.

Ware RT (2011) Slavery in Islamic Africa, 1400-1800. In: Eltis D, Engerman SL (eds) The Cambridge World History of Slavery, vol 3. Cambridge University Press, Cambridge, pp. 47-80.

Watson J (1980) Asian and African Systems of Slavery. University of California Press, Berkeley.

Weld TD (2011) American Slavery As it Is: Testimony of a Thousand Witnesses. University of North Carolina Press, Chapel Hill.

Westermann WL (1955) The Slave Systems of Greek and Roman Antiquity. American Philosophical Society, Philadelphia.

Wittman N (2012) Slavery Reparations Time is Now: Exposing Lies, Claiming Justice for Global Survival. Power of the TrInIty Publishers, Vienna.

US House (2005) Congressional-Executive Commission on China: Hearing 109, June 22. Government Printing Office, Washington. 
Yetman NR (ed) (2000) Voices from Slavery: 100 Authentic Slave Narratives. Dover Publications Inc, Mineloa.

\section{Legislation, International Documents, and Case Law}

An Act for the Better Ordering and Governing of Negroes (1661) (Barbados).

An Act Concerning Servants and Slaves (1705) (Virginia). [online] https://www.encyclopediavirginia.org/_ An_act_concerning_Servants_and_Slaves_1705[Accessed 21 November 2019].

An Act for the Subsistence, Clothing, and the Better Regulation and Government of Slaves (1816) (Jamaica) 57 Geo 3. Cap 25. [online] http://www.nlj.gov.jm/rai/CSEC/BookTheme2/Slave_Law_of_Jamaica.pdf [Accessed 21 November 2019].

Case concerning the Barcelona Traction, Light and Power Company Ltd (Belgium v Spain) [1970] ICJ Rep 3. Modern Slavery Act (2015) (United Kingdom). [online] http://www.legislation.gov.uk/ukpga/2015/30 /contents/enacted [Accessed 2 June 2020]

The Code Noir (1685). Translated by J. Garrigus. [online] https://s3.wp.wsu.edu/uploads/sites/1205/2016/02 /code-noir.pdf [Accessed 2 June 2020].

Case of the Hacienda Brasil Verde Workers v Brazil (Preliminary Objections, Merits, Reparations and Costs) [2016] Series C No 318 (Inter-American Court of Human Rights)

Prosecutor v. Kunarac, Vukovic and Kovac (Judgment) [2002] ICTY-96-23 and ICTY-96-23/1-A (International Criminal Tribunal for the Former Yugoslavia).

Siliadin v France [2005] App no 73316/01 (European Court of Human Rights).

League of Nations (1926a) Slavery Convention (adopted 25 September 1926, entered into forced 9 March 1927) League of Nations Treaty Series 60: 253.

League of Nations (1926b) Draft Convention on Slavery: Replies of Governments, Reply from the Government of the Union of South Africa. Publications of the League of Nations VI.B.

League of Nations (1926c) Slavery Convention: Report Presented to the Assembly by the Sixth Committee. Publications of the League of Nations VI.B.

Publisher's Note Springer Nature remains neutral with regard to jurisdictional claims in published maps and institutional affiliations. 